\title{
GENDER AND MUSIC-MAKING IN EXILE: FEMALE BOSNIAN REFUGEE MUSICIANS IN SLOVENIA
}

\author{
Alenka BARTULOVIĆ', Miha KOZOROG"
}

COBISS 1.01

\begin{abstract}
Gender and Music-Making in Exile: Female Bosnian Refugee Musicians in Slovenia This article explores the role of Bosnian refugee women in the music-making and organisational activities of two refugee bands (Dertum and Vali) in Slovenia in the early 1990s. Endorsing the ideas about the transformative power of art and looking beyond the dominant identitarian doxa that views music-making in exile as simply the preservation of the ethnic/national identity in a new context, the article places particular emphasis on the active role of women as creative agents of social change. It traces their role ethnographically not only in the process of reinvention of a traditional musical genre (the sevdalinka), but also in identity negotiations and transformation of the gender and power relations within and beyond the boundaries of the heterogeneous Bosnian refugee community, which had been shaped by the strict Slovenian migration policy.
\end{abstract}

KEY WORDS: women refugees, music-making, art and change, gender relations, sevdalinka, Bosnia and Herzegovina, Slovenia

\section{IZVLEČEK}

Spol in glasbeno ustvarjanje v begunstvu: Bosansko-hercegovske glasbenice begunke v Sloveniji Članek obravnava vlogo bosansko-hercegovskih begunk v organizacijskih dejavnostih in glasbenem ustvarjanju dveh begunskih glasbenih skupin (Dertum in Vali) v Sloveniji z začetka devetdesetih let. Ob upoštevanju idej o transformativni moči umetnosti in sočasnem zavračanju identitarne dokse, ki begunsko ustvarjalnost največkrat reducira na begunske težnje po ohranjanju nacionalne/etnične identitete $\mathrm{v}$ novih kontekstih, članek prikaže begunske ženske kot kreativne akterke družbenih sprememb. Etnografsko zasleduje njihovo vlogo pri transformaciji tradicionalnega glasbenega žanra - sevdalinke, prav tako pa pokaže na njihovo moč pri identitetnih pogajanjih ter spremembah razmerij moči ter razmerij med spoloma, in sicer tako znotraj heterogene bosansko-hercegovske begunske skupnosti kot tudi onkraj njenih - z migracijsko politiko - začrtanih meja.

KLJUČNE BESEDE: begunke, glasbeno ustvarjanje, umetnost in sprememba, odnosi med spoloma, sevdalinka, Bosna in Hercegovina, Slovenija

$\mathrm{PhD}$ in ethnology, assistant professor, researcher, Faculty of Arts, University of Ljubljana, Department of Ethnology and Cultural Anthropology, Aškerčeva 2, SI-1000 Ljubljana; alenka. bartulovic@ff.uni-lj.si

॥ PhD in ethnology, assistant professor, researcher, Faculty of Arts, University of Ljubljana, Department of Ethnology and Cultural Anthropology, Aškerčeva 2, SI-1000 Ljubljana; ZRC SAZU, Institute of Slovenian Ethnology, Novi trg 2, SI-1000 Ljubljana; miha.kozorog@ff.uni-lj.si 


\section{INTRODUCTION}

Over the last few decades we have witnessed the slow emergence of studies that have explored musical creativity in transitory or temporary migrant communities (e.g. Reyes 1986; Pesek 1996; Pettan 1996; Baily 1999; Golemović 2002; Andree Zaimović 2003; Kaiser 2006; Franz 2012; Kozorog 2015; Ögüt 2015). Migrants and refugees are increasingly recognised as a (potentially) innovative and creative force that makes a crucial contribution to the art scenes of their new or temporary homes (Cohen 1997; Baily, Collyer 2006). We have previously noted that the exploration of refugee creativity is frequently captured in a rigid identitarian framework (Kozorog 2015; Kozorog, Bartulović 2015), interpreted simply as the preservation of national/ethnic identity in exile. In such context other dimensions of art and creativity by migrants and refugees are often overlooked, including the process of the emergence of new identities, among others gender identities and the transformation of the power relations within and beyond the refugee community. Thus there is still a need for a more fundamental investigation of refugee and migrant creativity and its impacts, which should not be understood only through "integration" policies, but also through the generation of social change in both the migrants' lives and in the broader society.

This article explores the role of refugee women in music-making and organisational activities in Slovenia. We are primarily concerned with the refugee community ${ }^{1}$ and in particular the musical activities of female refugees from Bosnia and Herzegovina (B\&H), who found their (temporary) homes in Slovenia during the war in the 1990s. The paper explores the activity of women in two bands, Dertum and Vali, both of which were based in Ljubljana during the 1990s. Understanding women refugees as creative agents who employ their agency to invent new strategies to improve their status (see Cukut Krilić 2009; Milharčič Hladnik 2016), the article follows the (gender) identity negotiations within and beyond the heterogeneous Bosnian community, taking into account the broader (post-) Yugoslav context and Slovenian migration policy (see Đonlić, Črnivec 2003; Vrečer 2007; Cukut 2008).

The ethnographic article examines the circumstances and motivation behind the musically active refugee women. It is based on personal experience (one of the authors was involved in refugee music-making activities in the 1990s) ${ }^{2}$ and interviews with the members of the bands and their fans, conducted in the last few years. Through auto-ethnography and analysis of ethnographic material the article investigates the effects of female refugee creativity in the process of the hybridisation and active transformation of "traditional" music - namely the sevdalinka, and follows the changing gender and generational relations

1 Let us here acknowledge the invaluable contribution of the local organisations and individuals who organised and supported the refugees' activities (see Kozorog 2017). It is interesting to note that the crucial organisational roles in these organisations were played by women, e.g. Karmen Furlan, Majda Lenič, Eva Strmljan Kreslin etc. Because of the lack of space, a separate article will be dedicated to their significant role.

2 Alenka Bartulović was a singer with Vali. Miha Kozorog was enchanted by sevdalinkas after hearing the group Dertum. 
within the Bosnian refugee community. ${ }^{3}$ One particular focus is the dynamic dialogue amongst the refugees that was triggered by the opposing perceptions and experiencing of the sevdalinka as supposedly "authentic" Bosnian music. After the introduction of the refugee bands, the article traces the wider socio-economic and also material contexts of their emergence. Later it highlights the role of women in this process and concludes with an examination of the musical dialogue and a discussion of gender relations within the heterogeneous Bosnian community.

\section{INTRODUCING THE REFUGEE BANDS: DERTUM AND VALI}

It is important to take into account the fact that until just before the events described in this paper, the refugees from B\&H and their Slovenian "hosts" had been a part of the same Yugoslav state, which was also reflected in their music and musical tastes. At the time of the dissolution of Yugoslavia, the popularity of pop and rock bands from the "former homeland" experienced a surge in Slovenia (see Ceglar 1999; Stanković 1999). Unlike these popular bands, Dertum and Vali interpreted traditional songs from the same territory, yet their success can be partly interpreted as a legacy of the disintegration of Yugoslavia, which made the musical heritage from the Balkans attractive to a segment of the Slovenian public.

Even though Dertum and Vali shared a few key elements, their status on the Slovene music scene was quite different. Both bands were at least partially involved with established cultural organisations and projects in Ljubljana. Vali began its musical career under the patronage of the refugee project Cultural Weekend for Children from B\&H, which took place at the Vodnik Manor House cultural centre. Dertum applied the "do-it-yourself" approach, practicing in a small room at a refugee centre and later on relying on the logistics of the KUD France Prešeren youth cultural centre, where it became a part of the Exiles Project - a programme for empowering refugees. Regardless of the similarities relating to the inclusion of the bands into cultural institutions in Slovenia, they differed in the fact that the Cultural Weekend for Children from B\&H project was organised by the refugees themselves, while the Exiles Project was managed by the youth cultural centre. The two cultural centres also differed greatly, as KUD France Prešeren was oriented towards the production of "alternative culture", while the Vodnik Manor House focused on "high culture", predominantly literature. ${ }^{4}$ This had a certain influence on the music and careers of the two bands: Dertum attained cult status on the Slovene "underground" scene, while Vali worked with one of Slovenia's most popular musicians, Vlado Kreslin.

The bands were also connected by the fact that they both, in different stages of their existence, focused on performing traditional songs from various Yugoslav regions. The sevdalinka, which is understood as a Bosnian and regional musical heritage (Kozorog, Bartulović 2016), stood out in both cases. This repertoire made them recognisable on various Slovene

3 Our intention is to overcome the generalised and stereotypical representations of Bosnian women. Without neglecting some particularities of city life, we also intend to move away from the powerful notion of rural/urban dichotomy that completely occupied the field of analysis of gender roles and equality in $\mathrm{B} \& \mathrm{H}$. These studies sometimes overemphasise the progressiveness of the urban milieu and simultaneously diminish the heterogeneity of both urban and rural areas, where various interpretations of gender roles co-exist and collide.

The Vodnik Manor House also offered music lessons. 
music scenes, on which they functioned independently due to their different approaches to music, their different appearances and audiences. Vali was established by the music teacher Vjekoslav Andree. He was succeeded by his daughter, Vesna Andree Zaimović, ${ }^{5}$ who was responsible for the metamorphosis of the band's repertoire to sevdalinkas and other folk songs. Vali started off as a musical workshop at which young people learned to play various instruments by performing popular songs. With the shift towards traditional music the interest in this band grew amongst the Slovene public. Their cooperation with Slovene pop-rock star Vlado Kreslin stands out as a highlight in their career. The band recorded several songs and performed on the largest concert stages in Slovenia. Female vocalists was a special characteristic of Vali, and was innovative, since until then a vocal harmony interpretation of sevdalinkas had been almost unknown. Vali thus introduced polyphonic performance to a genre that was traditionally regarded as an intimate song, performed by a single vocalist. Due to the female vocalists and its prominent leader, the role of women was especially strong within the band.

Dertum was marked by a completely different local milieu, i.e. Slovenia's alternative music scene. The 1990s saw the emergence of the "world music" trend, which also grew in popularity in Slovenia. This pushed the band towards a focus on the Bosnian and Macedonian music traditions. To a great extent this change was effected by Farah Tahirbegović, ${ }^{6}$ a refugee from Zenica, who was a few years older than the boys in the band. Her creative path in fact started within the framework of the Cultural Weekend for Children from $\mathrm{B} \& \mathrm{H}$, where she influenced the musical taste and the embracing of sevdalinkas by Vesna Andree Zaimović (Andree 2009). As a vocalist she joined a few teenagers, her fellow residents at the refugee centre, who were musicians and members of a rock group called Durum, and swayed them with new ideas, especially as a connoisseur and lover of traditional music, sevdalinkas in particular. Once she was in the band another two female vocalists joined, creating a dynamic of boys who played instruments and mainly female singers. Sticking to the "world music" trend, the band established a cult status on the Slovene alternative scene, which was a result of their innovative musicianship, tireless performing, and especially their first live CD, recorded at KUD France Prešeren, with a great soundscape that was partially formed by the almost bodily presence of the enthusiastic audience. ${ }^{7}$ The origins and popularity of both bands, however, have to be understood in the framework of Slovenian migration policy and the disintegration of the former shared country.

\section{WOMEN AND “TEMPORARY REFUGEE” STATUS IN SLOVENIA}

Most of the refugees who came to Slovenia at the outbreak of the war in B\&H were women, children and youth. ${ }^{8}$ Their practices of confronting the limitations of refugee status were extremely diverse, just like the factors that influenced the quality of their lives in Slovenia.

5 She later defended an MA in Ethnomusicology and wrote a few scholarly articles on refugee music-making (e.g. 2003).

6 Farah Tahirbegović (1973-2006) studied literature. After the end of war she returned to Sarajevo and managed the renowned Sarajevo bookshop and publishing house Buybook, where she was the editor-in-chief.

7 The band's second and last CD was a studio album.

8 Natalija Vrečer states that $80 \%$ of the refugees were women (2007: 119). 
Researchers have already isolated the problematic aspects of Slovenian migration policies (see Vrečer 2007). While a number of former refugees highlighted the experienced ghettoisation in the (remote) refugee centres, ${ }^{9}$ others stressed the limited access to work as the most damaging obstacles to the integration of refugees into Slovene society. It should be noted that in Slovenia the rights of refugees were curbed by the status of "temporary refugee". However, many refugees managed to fight its limitations, both through personal resourcefulness and some also with the help of engaged individuals and institutions (see Đonlić, Črnivec 2003; Vrečer 2007; Cukut Krilić 2008, 2009; Kozorog 2015, 2017). This was most evident in the engagement of women in modifying the restrictive policies that stipulated that people with temporary refugee status could only perform temporary jobs (see Đonlić, Črnivec 2003: 90). In the context of systematic inequality, according to some studies (see for example Cukut Krilić 2008, 2009), women showed great resourcefulness and also managed to exploit the control mechanism for their own benefits and self-fulfilment. It is thus not surprising that the researchers in migration studies who have indulged in the process of deconstructing the dominant image of migrant and refugee women as victims over the last few decades have drawn attention to the gender aspects of the integration process. In this respect it is of crucial importance to explore gender-specific control in the context of migration and the reconfiguration of the gender relations through mobility (see Pessar 1999; Silvey 2004; Milharčič Hladnik, Mlekuž 2009; Vidmar Horvat 2014; Milharčič Hladnik 2016).

In her comparative research on the strategies of dealing with the refugee status in the USA and Austria, Barbara Franz has shown how different migration policies influenced the change in gender relations (2005). ${ }^{10}$ She interpreted these changes mainly as a reaction to structural obstacles, emphasising that, in contrast to New York, in Austria Bosnian women became financial providers for their families precisely because of the strict employment policy and the availability of low-paid work for women on the black market. A similar situation could be observed in Slovenia, where Sanja Cukut noted that "women took care of survival, as men could not work publicly due to the greater control enforced over the more traditional male jobs (for instance construction work)" (2008: 71). However, she confirms the fact that the empowerment of women should not be considered merely a consequence or effect of the limitations or opportunities of the migration policy, since it is often guided by the women's ambitions for self-fulfilment and active engagement in rebuilding their lives (Cukut Krilić 2009). In some cases it is connected with the different gendered experiences of migration. For example, in research on masculinity of Bosnian refugees in Australia, Stef Jansen (2008) ascertained that men experienced their refugee status mainly as an obstacle, while women were more likely to perceive it as a challenge and opportunity. Although some researchers of Bosnian refugees in Slovenia (see Vrečer 2007) argue that this was not the case, our research findings confirm that this also held true for the segment of refugee youth in Slovenia.

Yet it should be noted that women's proactive role could be read as both: sometimes as a fulfilment of traditional gender roles, since on the level of national discourses women were often regarded as mothers who need to sacrifice themselves for the sake of the

9 Some of the refugee centres were opened in the city centres, however - as many interlocutors confirmed - this did not alleviate the general feelings of exclusion.

10 Her data was collected at the end of the 1990s. 
well-being of the children, and also as modern women who manage to keep their societal position or find new opportunities in the new environment. Sometimes these positions were not perceived as mutually exclusive. What should be emphasised when talking about women refugees from $\mathrm{B} \& \mathrm{H}$ is the fact that several generations of Bosnian women grew up and lived in ideological frames that promoted the socialist model of a modern, emancipated woman. ${ }^{11}$ This model stressed the importance of employment for establishing gender equality. Official Yugoslav ideology presented economic independence as "the key factor to female emancipation" (Hofman 2012: 123). The power of this conviction was undoubtedly reflected in the engagement of the Bosnian women refugees in their search for employment. At the same time, various ethnographic studies explored complex and opposing understandings and practicing of gender roles in - extremely heterogeneous - socialist B\&H (see Sorabji 1989; Helms 2003; Bringa 2009). Regardless of the Yugoslav ideology of gender equality and women's emancipation, the wide diversity in the practicing of gender roles speaks in favour of the thesis of the co-existence of socialisms with "different, often unharmonised faces" (Hofman 2012: 152). The heterogeneity of interpretations and practicing of gender roles that cannot be explained easily by evoking the stereotypical notion of urban/ rural dichotomy was faithfully preserved among Bosnian refugees, which is reflected also in female engagement in creative and artistic practices.

\section{THE “BIRTHPLACE” OF REFUGEE MUSIC: FROM COLLECTIVE CENTRES TO POPULAR CONCERT VENUES}

Apart from the limited right to work, one of the key factors that influenced the refugees' wellbeing were the material living conditions. In Slovenia a high percentage of refugees lived in refugee centres, where - as our interlocutors emphasised - the general atmosphere was often demotivating and depressing. The feeling was strengthened by the lack of privacy in the overcrowded buildings and (in the initial period) rooms (see Vrečer 2007). People with various backgrounds, interests, goals, desires, professional paths, education levels, ideological preferences, aspirations, etc. were placed together and had to invent their own strategies of survival. In this context it proved extremely difficult for many to incorporate the diverse lifestyles and opposing ideologies. The narrations of the past and aspirations for the future were clearly conceived in the context of (more or less evident) societal exclusion (cf. Malkki 1995). Youth in particular had to carve their own free space, since they were often trapped between the marginalised social position, boredom and the pervasive control of the older inhabitants of the centres (see Kozorog 2017). In Room 135C at the Šmartinska street refugee centre in Ljubljana, shared by two youngsters, a group of teenagers and youngsters spontaneously created a space for socialising and creativity, where Dertum was born. Playing music was a form of escapism and a search for enjoyment during the refugee years, or as Maida, a singer in the band, explained: "No strategies, no marketing, no managers, a bit of promotion, all together nothing! Everything was ad hoc, spontaneous, a bit of this and a bit of that, fooling around, partying, we had a great time!" It seems that it was

11 Lately there has been a visible increase in literature on the Yugoslav socialist production of the modern woman and the discrepancy between the political promotion of gender equality and its implementation (see Ramet 1999; Jambrešić Kirin, Blagaić 2013; Hassenstab, Ramet 2015). 
precisely the experience of living in the collective centre, supported by a certain degree of societal exclusion and boredom, that encouraged young refugees to persist in their "rebellious" positions. They focused on their personal and cultural re-invention, which enable them to overcome the obstacles of refugee status and even exploit some of the limitations for their own benefit.

Vali's beginnings were different, since they emerged in the framework of the aforementioned project led by refugees. However, feelings of exclusion, which of course did not affect everyone from the refugee community equally, ${ }^{12}$ were also an important trigger for the formation of this band. That is, due to the spatial limitations and the demands of the Bosnian government, refugee children could not enrol in Slovenian elementary schools at the beginning of the 1990s (see Hočevar 2001) and thus - in spite of the efforts of certain individuals - had to attend a parallel educational system at the refugee centres. Furthermore, because of their social standing and lack of finances, extracurricular activities were also unavailable for many refugees. This inspired the music teachers from the Ilidža music school in Sarajevo who had found their temporary home in Ljubljana to organise a project that gathered refugee children (both those living at the refugee centres as well as those who lived in private accommodations) ${ }^{13}$ and enable them to socialise through music and other creative activities. However, the musical ambitions of the band leader, Vesna Andree Zaimović, the increased interest of the Slovenian public in "traditional Bosnian music", the motivation of some local supporters and the youth's enjoyment of music-making led to the gradual recognition of the band, making it possible for Vali to perform at a number of Slovenian concert venues. Vesna Andree Zaimović dictated the decisive steps, when inspired by conversations with Farah Tahirbegović about the importance of the Bosnian musical heritage - she embraced the sevdalinka as a tool for breaking the chains of refugee marginalisation in Slovenia:

The traumatic experiences of the refugees, caused by the organized violence in their homes, forced deportations, the disruption of a deeply rooted way of life and separation from their original social surroundings, were not resolved in exile. In fact, the collective refugee camps organized as a ghetto in which there was no privacy and no everyday responsibilities, together with the refugees' inability to acquire work visas, which forced them to live at the existential minimum, destroyed optimism and marginalized the identity that each person had acquired over the years. (Andree Zaimović 2001: 111-112)

For this reason she defined the sevdalinka as a musical form that "confirms the cultural identity of $\mathrm{B} \& \mathrm{H}$, which at this delicate moment and in a very short period of time has had to replace the Yugoslavian national identity" (2001: 113-114). In addition, she used this music "against negative and incorrectly based stereotypes about the traditional and present culture of $\mathrm{B} \& \mathrm{H}$ by presenting authentic cultural and therefore musical expression of B\&H” (2001: 112).

12 As we have already noted, the refugees in Slovenia faced different degrees of exclusion. Also people managed their status differently.

13 The interlocutors that worked with the children at the Vodnik Manor House claimed that refugee children living in private accommodations at the beginning seemed even more isolated than those at the refugee centres. 
The importance of the role of women in this process, which testifies to the power of music and art to redefine the living standard of refugees and their position in the new society, is clear. Minka Đonlić, a member of Vali and a music teacher who organised a series of music workshops for refugee children, ${ }^{14}$ says that she was saved by music during her refugee years. Upon her arrival in Slovenia she was not able to enrol into secondary school, and therefore she was often bored in her aunt's one-room apartment in Postojna. As she was used to having a rich social and musical life in Tuzla, she "walked around looking for some sort of action. Not a party, something substantial." She found contact with other youths at the Postojna military barracks, which had been transformed into a refugee centre in the 1990s. The courtyard became a space for socialising, where the youth gathered and played Yugoslav pop-rock classics. Her life changed when she moved to the Vic refugee centre in Ljubljana, where the social worker sent her to Vodnik Manor House and engaged her as a music teacher. ${ }^{15}$ Being involved in the teaching process increased her self-esteem, and this opened the doors to new opportunities and projects. Similarly to others involved in the musical activities, Minka understood music as a medium that humanised refugees' lives. Music enabled the creation of parallel and more manageable worlds within the highly controlled environment of the refugee centres, and could also be used to penetrate the consciousness of the broader Slovene public. In some ways, musical creativity narrowed the gap between the refugees and the "hosts", so it comes as no surprise that certain members of Dertum and Vali, as well as other refugee musicians, remember their successful musical career and the refugee period with nostalgia (cf. Kozorog 2015). It was a period that for many symbolised an important personal transformation (in public perception): from being simply seen as one of the refugees they became acknowledged and appreciated as individuals and musicians.

\section{THE ROLE OF WOMEN IN THE REINVENTION OF THE SEVDALINKA IN SLOVENIA}

Scholars researching the status of women in socialist Yugoslavia have argued that despite the political endeavours for achieving gender equality - which undoubtedly significantly improved the status of women in all Yugoslav republics - the state failed to address the intimate sphere and the importance of family relations and rooted patriarchal patterns for women's emancipation (see Irvine, Sutlović 2015). What was often emphasised is the fact that during the modernisation processes that fostered women's employment, financial independence and gender equality, socialist Yugoslavia often imposed a "double burden"16 upon women. The legacy of socialist emancipation could also be traced within the heterogeneous Bosnian refugee community.

14 She also led therapeutic music workshops for other underprivileged groups in Slovenia.

15 Đonlić was an active member of the Cultural Weekend for Children from B\&H, where she taught piano and accordion. Following the departure of Vesna Andree Zaimović she also took over the leadership of Vali, with whom she had previously performed as a singer and occasional instrumentalist.

16 Here the term "double burden" is used to emphasise the responsibility of women to do the majority of the unpaid domestic labour, while also being employed outside the household. 
The importance of (women's) education was emphasised as a crucial path for ensuring gender equality (see Ramet 1999). While most of the adult refugee women in Slovenia struggled to find employment, most of the girls from refugee bands managed to enrol in secondary schools or universities. Our female interlocutors understood education as a part of their personal identity and life goals. Even though they were focused on education, they - especially the older girls who lived in refugee centres - took over a large share of the care and responsibility for their loved ones. This often extended from family members to children and youth who arrived in Slovenia without their parents. By combining their studies with the caregiving role, the young girls took on a double burden, which was - as our interlocutors claim - often expected, but also praised amongst refugees. For example, Farah Tahirbegović was frequently described as a substitute mother figure. Yet she also became a prominent cultural activist. She used art and music both to explain her experiences of war and exile and as a tool for social criticism, especially the rising nationalism in $\mathrm{B} \& \mathrm{H}$ and also amongst the refugees. The film Sevdah, ${ }^{17}$ which documented the revitalisation of the sevdalinka after the dissolution of Yugoslavia, illustrates Farah's initiative in guiding individuals towards the musical tradition of $\mathrm{B} \& \mathrm{H} .{ }^{18}$ This is also evident in a statement by Vali's leader Vesna Andree Zaimović that the sevdalinka was rather unimportant for her until her refugee years. She only became addicted to it once she was in Slovenia and only through socialising with Farah, who was, as she said, the one who planted the love for sevdalinka in her. The film also features the internationally acclaimed sevdalinka performer Damir Imamović, who also acknowledged the importance of Farah's role not only in the process of the reinvention of the sevdalinka, but also in influencing him to pursue a music career in this genre.

The visible role played by Farah and other women in the (re)invention of the tradition can be interpreted in two ways: as a confirmation as well as a negation of the role ascribed to women in the music-making process. In a widely-held dogmatic belief and especially in national ideologies, women are often perceived as the guardians of tradition, committed to the transmission and preservation of heritage (Hofman 2012: 51; Karača Beljak, Talam 2015: 7). Both traditional music and the contemporary global music business are in fact still male-dominated (see Bradby 1993; Talam 2015). The sevdalinka was no exception. Bosnian ethnomusicologist Jasmina Talam writes that in Bosnian traditional music there is a clear male dominance over instrumental musicianship. Female instrumentalists were long considered an aberration. Therefore the archives mention only a few exceptions that merely confirm the rule (Talam 2015: 34). The role of women in the music scene changed radically in socialist $\mathrm{B} \& \mathrm{H}$, but in most cases - as far as the sevdalinka was concerned - women were known mostly as vocalists. In Dertum and Vali this division of musical gender roles was seemingly rather rigid - men played the instruments, while women sang. In reality, the role of women in these bands was much more subversive. For example, most of the girls played instruments, since many of them had obtained musical education in $\mathrm{B} \& \mathrm{H}$, and some of

17 The word sevdah is often used as a synonym for sevdalinka.

18 The documentary was directed by Marina Andree Škop, the sister of Vesna Andree Zaimović. She also held filmmaking and animation workshops within the project Cultural Weekend for Children from B\&H. 
them contributed to the arrangements, the formulation of the repertoire etc. ${ }^{19}$ They played a crucial role in the organisation of the bands. Even though it seems at first glance that they accepted the conservative role as the "guardians" of tradition, in the sense that they knew a variety of sevdalinkas and introduced them to the bands' repertoires, they in fact managed to produce a new ideological platform for the innovative reinterpretation of the genre. Knowledge of Bosnian musical traditions was thus used to contradict conservative ideologies, in particular to oppose the dominant narratives about B\&H in Slovenia. A part of their struggle was however also connected with gender roles.

\section{AGAINST NORMATIVE FEMININITY:THE NEW SEVDALINKA}

Due to the combination of the unconventional way in which the sevdalinkas were performed, the disintegration of Yugoslavia and the rise in the popularity of world music, Dertum and Vali attracted a great amount of interest, especially amongst the younger Slovenian audience. This was to a certain degree surprising, as the sevdalinka was neither known nor popular in Slovenia. ${ }^{20}$ Some Dertum fans explained that they were in fact repelled by this music until they heard Dertum. The aversion to "southern howling", as the specific way of singing was perceived in Slovenia, was deeply rooted, thus the open enthusiasm of Slovenian public also came as a great surprise to the members of the two bands. Of course, their audience also included a number of young immigrants from $\mathrm{B} \& \mathrm{H}$, although - as the band members claimed - they were not as popular amongst the older generation of refugees and members of the Bosnian diaspora. ${ }^{21}$ In fact, many remained unconvinced by their reinterpretation of sevdalinkas. Some were intrigued, while others were completely disinterested in the reinvented music, but many regarded the collaboration between Vali and Vlado Kreslin, which had a great impact on the popularisation of the sevdalinka and the Bosnian music tradition in Slovenia, as another violation of unwritten musical rules. In addition, Dertum and Vali used instruments and rhythms that were not typical for sevdalinkas, and many opined that the vocal interpretations sounded rather unusual (Đonlić, Črnivec 2003: 45). Dertum, which was in many ways even more experimental than Vali, received similar criticism on their tour of B\&H: "You have various factions. You have those who say: 'Oh no, why are they ruining the sevdalinka for us? Where is the accordion?"' The band members recall similar attitudes amongst the Bosnian refugees, for whom they continuously performed at the refugee centres throughout Slovenia. Their activity was mostly tolerated, but not actively supported. Maida remembered a concert that the band performed at the refugee centre on Šmartinska street that clearly showed the diverse lifestyles of Bosnian refugees:

19 For example, Vesna Andree Zaimović wrote most of the arrangements for Vali. She also started to play the saz, an instrument which still remains predominantly in the male domain. In 1999 she also played saz in the band that represented B\&H at the Eurovision Song Contest.

20 However, rock bands such as Bijelo dugme or Azra, which were inspired by folk music from the Balkans (including sevdalinkas), were popular.

21 According to the one interlocutor, who was involved in the activities of the Bosnian diaspora in Slovenia which had been formed already before the dissolution of Yugoslavia, their members did not attend the concerts of refugee bands. And when organising their own events they preferred to invite musicians who played sevdalinkas in a more conventional way. 
Do you know how they looked at us, the older women from the villages? Benjo had a ponytail, Erol a ponytail, Marjan a ponytail, hair down to here, Farah was wearing loose jeans and sneakers. "Oh, just look at these kids. Oh well, let them play and sing." There was not a lot of interest in our concert, but we were tolerated.

Diverse lifestyles and understanding of gender roles was also evident in the criticism of young performers among a segment of refugees. Since women often carry the "burden of representation" (Yuval Davis 2003: 17) and since the sevdalinka was becoming the representational music of Bosnian nationals, it is not surprising that women performers were subjected to certain forms of social control. After all, the girls who performed in bands were the most visible part of the refugee community, hence they became responsible for the correct public representation of their compatriots in Slovenia. For a certain segment of refugees, the girls in the bands did not conform to their expectations. Some refugees believed that the singers were old enough to become serious and start planning a family. Their wandering in "inappropriate" places, such as student and youth clubs, sometimes provoked strong disapproval. Remembering their refugee years, the band members recalled the criticism of older generations, mostly women. ${ }^{22}$ The image of the singers in Dertum for example differed greatly from the dominant cultural model for female public figures. Even though the norms permitted provocative dressing for female singers, sometimes even bordering on vulgarity (see Hofman 2010), female singers in Yugoslavia were mainly an expression of modern femininity. The "uniform" of the singers in Dertum was casual, often consisted of jeans and All-Star sneakers, both unisex and a symbol of "urbanity". Farah and Maida also had short haircuts, which was also in opposition to the idea of what a (young) female singer should look like. Minka Đonlić also encountered negative responses from the more conservative members of the refugee community because of her looks and musical activities.

Controlling the appearance and behaviour was disturbing for the girls in the bands, as most of them came from open and tolerant family and social environments, in which children were brought up in the spirit of socialist gender equality. This is also evident from the girls' musical education. Vesna and Minka were both raised in musical families that supported their music careers. Maida's family was not professionally involved in music, but singing played an important part in her upbringing, since it was a key component at all of the family gatherings. ${ }^{23}$ Farah played the accordion and finished primary music school in Zenica. Music education and playing at home was in fact often accepted even among the more conservative part of the refugee community, yet when the same girls appeared as independent performers on the public music scene in a "semi-foreign" country, different attitudes and views clashed. Hence, due to their liberal views young women were forced to enter into negotiations with their surroundings. The sevdalinka, as an important element of musical heritage, turned into a battlefield. The battle addressed the status of music and its performance styles, but also the understanding of gender roles. The controversial sevdalinka served as tool for the emancipation of the youth, especially the young women, in the highly demanding new social context, where conflicting expectations proved to be extremely demanding. It served as a message that in the same way as the sevdalinka can be

22 The habitual manner of dress for women has also proven to be a focus in other integration contexts (see for example Huisman, Hondagneu Soelo 2005).

23 It should also be mentioned that her mother appeared as a guest on Dertum's second album. 
complex and experimental, allowing for various different approaches to its performance, the same complexity should be admitted when gender relations and women's appearance is concerned.

\section{CONCLUSION}

In an interview with the ethnomusicologist Amra Toska, Emina Zečaj stated that in the Yugoslav context the Bosnian music scene was marked by patriarchal attitudes and Islamic morals, which were often aligned with the predominant understanding of moral behaviour. Despite the Yugoslav promotion of gender equality, it was - according to a well renowned sevdalinka singer - still shameful for women to be professionally involved in the music business. However, as a good vocalist with a bright future, Emina Zečaj opted for a singing career, also because, as a single mother, she had to take care of her children (cf. Toska 2015: 81):

Music is a tough path. If you want music to feed you [...] It is all nice, but it is a tough path. What will you wear, what will people say? People never leave you alone, if you are at least slightly hard-working and attractive, men will not leave you alone. You have to avoid them. The morals are lost.

In the 1990s the pressure on women in the area of former Yugoslavia, including B\&H, increased. The national ideologies and religious communities contributed to the process of the retraditionalisation of gender roles, undermining the positive gains of the Yugoslav policy of gender equality (see Helms 2008; Bartulović 2015). The process had also influenced part of the (already extremely heterogeneous) Bosnian diaspora and refugee community, including the people who found their (temporary) home in Slovenia. The manner in which Bosnian girls and women confronted their refugee status in Slovenia showed characteristics of the double influence migrations have on gender roles - a simultaneous strengthening and disintegration of patriarchal patterns (see Pessar 1999: 53). On one hand, many Bosnian refugees reported that the retraditionalisation of gender roles was pervasive in refugee centres around Slovenia, where social control was prevalent, while on the other hand, various initiatives (organised by refugees or Slovenian organisations and individuals) supported gender equality and gave a place to initiatives of both women and men, but mainly youth. With their active role in these and also other activities, women contributed not only to defending gender equality, but also to improving their own life (and the lives of their families and friends) and enabled the creation of less-stereotypical images of B\&H in Slovenia. Here, music, and especially the sevdalinka, played a significant role.

In the 1990s the sevdalinka became a visible national symbol of $\mathrm{B} \& \mathrm{H}$, and in particular it was also appropriated by the national community as an exclusive national heritage (Kozorog, Bartulović 2016). Yet at the same time it also became a tool for social criticism within the refugee community and later on also in B\&H. Because Vali and Dertum were characterised by the participation of high numbers of girls, the appearance of the issue of gender roles and social expectations of (female) youth was inevitable. Dertum also regularly performed during night hours, in rock clubs, as well as in the Metelkova City squat, i.e. in places that did not have the best reputation among the general public. In addition, the girls 
in Dertum did not adhere to the ideas of the normative femininity that had been nurtured in socialist Yugoslavia. With their role in organising the bands, performing and reinventing the sevdalinka together with their peers, the female members not only rejected the retraditionalisation of the music, but also gender roles. Female refugees used music to move from a spatially and socially peripheral position into the very centre of the music scene in Slovenia, to large festivals and important stages of renowned cultural institutions in their new (temporary) home. Geographic and social mobility influenced their self-perception and esteem, which was also noticed upon their return to $\mathrm{B} \& \mathrm{H}$, where many of the girls from refugee bands made a significant mark on the local cultural scenes. ${ }^{24}$ Farah, Vesna, Minka, Maida and others involved in the various cultural activities during the 1990s were facilitators and organisers as well as ideologists, and through these roles they managed to open a window on a different understanding of their position in Slovenia and explore the opportunities offered by the newly emerged circumstances. Hence, the reinvention of the sevdalinka in Slovenia in the 1990s confirms that the crucial element of enabling refugees' participation is to focus on the empowerment of individuals and the collectives they create (Franz 2012: 283-284). Thus a true integration of differences is made possible, because the process of personal and musical reinvention would be much more difficult without the cooperation of local activists, organisations and the general public. In the case at hand, the latter in fact embraced the new sevdalinka and its performers, even though the performers sometimes felt alienated from their fellow refugees.

\section{REFERENCES}

Alajaji, Sylvia Angelique (2015). Music and the Armenian Diaspora: Searching for Home in Exile. Bloomington, Indianapolis: Indiana University Press.

Andree, Marina (2009). Sevdah. Studio Dim. DVD.

Andree Zaimović, Vesna (2001). Bosnian Traditional Urban Song "On the Sunny Side of the Alps": From the Expression of Nostalgia to a New Ethnic Music in Slovene Culture. Music and Minorities (eds. Svanibor Pettan, Adelaida Reyes, Maša Komavec). Ljubljana: Založba ZRC, ZRC SAZU, 111-120.

Andree Zaimović, Vesna (2003). Muzički izrazi bosanske dijaspore u zapadnoevropskoj kulturi. Master's Thesis. Sarajevo: University of Sarajevo.

Baily, John (1999). Music and Refugee Lives: Afghans in Eastern Iran and California. Forced Migration, December, 10-13.

Baily, John, Collyer, Michael (2006). Introduction: Music and Migration. Journal of Ethnic and Migration Studies 32/2, 167-182.

Bartulović, Alenka (2015). Islam and Gender in Post-war Bosnia-Herzegovina: Competing Discourses in Everyday Practices of Muslim Women. Gender (In)Equality and Gender Politics in Southeastern Europe: A Question of Justice (eds. Christine M. Hassenstab, Sabrina P. Ramet). Basingstoke, New York: Palgrave Macmillan, 274-296.

24 For example, Farah Tahirbegović, as one of the more visible participants in the events described, had a successful career in nurturing and guiding the development of the emergent literature and music scene in B\&H. Aida Čorbadžić, another singer within Dertum, became an opera singer in Sarajevo. Vesna Andree Zaimović engaged in the Bosnian music scene as an ethnomusicologist and journalist. 
Bradby, Barbara (1993). Sampling Sexuality: Gender, Technology, and the Body in Dance Music. Popular Music 12/2, 155-176.

Bringa, Tone (2009). Biti musliman na bosanski način: Identitet i zajednica u jednom srednjobosanskom selu. Sarajevo, Zagreb: TKD Šahinpašić.

Bohleman, Philippe V. (2001). Diaspora. Grove Music Online, (22. 12. 2016).

Ceglar, Miha (1999). Balkan scena. Urbana plemena - subkulture na Slovenskem $v$ devetdesetih (eds. Peter Stankovič, Gregor Tomc, Mitja Velikonja). Ljubljana: Študentska založba, 75-82.

Cohen, Robin (1997). Global Diasporas. London: UCL Press.

Cukut, Sanja (2008). Ženske kot akterke migracijskih procesov: Prisilne priseljenke iz Bosne in Hercegovine. Glasnik Slovenskega etnološkega društva 49/3-4, 71-77.

Cukut Krilić, Sanja (2009). Spol in migracija: Izkušnje žensk kot akterk migracij. Ljubljana: Založba ZRC, ZRC SAZU.

Đonlić, Hazemina, Črnivec, Vesna (2003). Deset let samote: Izkušnje bosansko-hercegovskih begunk in beguncev v Sloveniji. Ljubljana: Društvo Kulturni vikend.

Golemović, Dimitrije O. (2002). Tradicionalna narodna pesma kao simbol novog kulturnog identiteta. (Na primeru prakse jugoslovenskih ratnih izbeglica). Novi zvukinternacionalni časopis za muziku 19, 57-65.

Franz, Barbara (2005). Uprooted and Unwanted: Bosnian Refugees in Austria and the United States. College Station: Texas A\&M University Press.

Franz, Barbara (2012). Immigrant Youth, Hip Hop and Feminist Pedagogy: Outlines of an Alternative Integration Policy in Vienna, Austria. International Studies Perspectives $13 / 3,270-288$.

Hassenstab, Christine M., Ramet, Sabrina (eds.) 2015. Gender (In)Equality and Gender Politics in Southeastern Europe: A Question of Justice. Basingstoke, New York: Palgrave Macmillan.

Helms, Elissa (2008). East and West Kiss: Gender, Orientalism, and Balkanism in Muslim-Majority Bosnia-Herzegovina. Slavic Review 67/1, 88-119.

Helms, Elissa (2003). Gendered Visions of the Bosnian Future: Women's Activism and Representation in Post-War Bosnia-Herzegovina. Doctoral dissertation. Pittsburgh, Pa.: University of Pittsburgh.

Hemetek, Ursula, Bajrektarević, Sofija (2000). Bosnische Musik in Österreich: Klänge einer bedrohten Harmonie. Vienna: Institut für Volksmusikforschung und Ethnomusikologie.

Hikmet Öğüt, Evrim (2015). Transit Migration: An Unnoticed Area in Ethnomusicology. Urban people 17/2, 269-282.

Hočevar, Andreja (2001). Osnovnošolsko izobraževanje beguncev v Sloveniji. Sodobna pedagogika 52/2, 142-163.

Hofman, Ana (2010). Kafana Singers: Popular Music, Gender and Subjectivity in the Cultural Space of Socialist Yugoslavia. Narodna umjetnost 47/1, 141-161.

Hofman, Ana (2012). Socialistička ženskost na sceni: Rodne politike u muzičkim praksama jugositočne Srbije. Beograd: Evoluta.

Husiman, Kimberly, Hondagneu Sotelo, Pierrette (2005). Dress Matters: Change and Continuity in the Dress Practices of Bosnian Muslim Refugee Women. Gender and society 19/1, 44-65. 
Irvine, Jill A., Sutlović, Leda (2015). Gender Equality in Croatia: Closing the Compliance Gap. Gender (In)Equality and Gender Politics in Southeastern Europe: A Question of Justice (eds. Christine M. Hassenstab, Sabrina P. Ramet). Basingstoke, New York: Palgrave Macmillan, 62-86.

Jambrešić Kirin, Renata, Blagaić, Marina (2013). The Ambivalence of Socialist Working Women's Heritage: A Case Study of the Jugoplastika Factory. Narodna umjetnost 50/1, 40-73.

Jansen, Stef (2008). Misplaced Masculinities: Status Loss and the Location of Gendered Subjectivities amongst "Non-transnational" Bosnian Refugees. Anthropological Theory $8 / 2,181-200$.

Kaiser, Tania (2006). Songs, Discos and Dancing in Kiryandongo, Uganda. Journal of Ethnic and Migration Studies 32/2: 183-202.

Karača Beljak, Tamara, Talam, Jasmina (2015). Uvodna riječ urednica. Žene nositeljice narodne muzičke prakse u Bosni i Hercegovini (Women as Bearers of Folk Music Practices in Bosnia and Herzegovina) (eds. Tamara Karača Beljak, Jasmina Talam). Sarajevo: Muzička akademija Univerziteta u Sarajevu, ICTM Nacionalni komitet Bosne i Hercegovine, 5-8.

Kozorog, Miha (2015). Prilog etnomuzikološkim istraživanjima ratnih izbjeglica iz Bosne i Hercegovine: "Nešto između”. Muzika 19/1, 20-31.

Kozorog, Miha (2017). Doubly Excluded, Doubly Included, "Something in-between”: A Bosnian Refugee Band and Alternative Youth Culture in Slovenia. Sounds of Attraction: Yugoslav and Post-Yugoslav Popular Music (eds. Miha Kozorog, Rajko Muršič). Ljubljana: Znanstvena založba Filozofske fakultete Univerze v Ljubljani, 73-97.

Kozorog, Miha, Bartulović, Alenka (2015). The Sevdalinka in Exile, Revisited: Young Bosnian Refugees' Music-making in Ljubljana in the 1990s (a note on applied ethnomusicology). Narodna umjetnost 52/1, 121-142.

Kozorog, Miha, Bartulović, Alenka (2016). Sevdah Celebrities Narrate sevdalinka: Political (Self-) Contextualization of sevdalinka Performers in Bosnia-Herzegovina. Traditiones 45/1, 161-179.

Malkki, Liisa (1995). Purity and Exile: Violence, Memory, and National Cosmology Among Hutu Refugees in Tanzania. The University of Chicago Press.

Milharčič Hladnik, Mirjam (2016). Nadzor nad nadzorom: Strategije upiranja in avtonomnosti delovanja migrantk v sodobni in zgodovinski perspektivi. Dve domovini / Two Homelands 43, 35-46.

Pesek, Albinca (1996). Music as a Tool to Help Refugee Children and Their Mothers: The Slovenian Case. War, Exile, Everyday Life: Cultural Perspectives (eds. Renata Jambrešić Kirin, Maja Povrzanović). Zagreb: Institute of Ethnology and Folklore Research, 257-263.

Pessar, Patricia R. (1999). The Role of Gender, Households, and Social Networks in the Migration Process: A Review and Appraisal. The Handbook of International Migration: An American Experience (eds. Charles Hirschman, Philip Kasinitz, Josh DeWind). New York: Russell Sage Foundation, 53-70.

Pettan, Svanibor (1996). Making the Refugee Experience Different: “Azra” and the Bosnians in Norway. War, Exile, Everyday Life: Cultural Perspectives (eds. Renata Jambrešić Kirin, Maja Povrzanović). Zagreb: Institute of Ethnology and Folklore Research, 245-255.

Povrzanović Frykman, Maja (2009). Views from Eithin: Bosnian Refugees' Experiences Related to their Employment in Sweden. Resettled and Included? The Employment Integration of Resettled Refugees in Sweden (eds. Pieter Bevelander, Mirjam Hagström, Sofia Rönnqvist). Malmö: Malmö University, European Refugee Fund, 81-128. 
Ramnarine, Tina K. (ed.) (2007). Musical Performance in the Diaspora. London, New York: Routledge.

Ramet, Sabrina (1999). In Tito's Time. Gender Politics in the Western Balkans: Women and Society in Yugoslavia and the Yugoslav Successor States (ed. Sabrina P. Ramet). University Park, Pa.: Pennsylvania State University Press, 89-105.

Reyes Schramm, Adelaida (1986). Tradition in the Guise of Innovation: Music among a Refugee Population. Yearbook for Traditional Music 18, 91-101.

Reyes, Adelaida. (1999). Songs of the Caged, Songs of the Free: Music and the Vietnamese Refugee Experience. Philadelphia: Temple University Press.

Scheding, Florian, Levi, Erik (eds.) (2010). Music and Displacement: Diasporas, Mobilities, and Dislocations in Europe and Beyond. Lanham, Md.: Scarecrow Press.

Silvey, Rachel (2004). Power, Difference and Mobility: Feminist Advances in Migration Studies. Progress in Human Geography 28/4, 490-506.

Stankovič, Peter (1999). Rokerji s konca tisočletja. Urbana plemena - subkulture na Slovenskem $v$ devetdesetih (eds. Peter Stankovič, Gregor Tomc, Mitja Velikonja). Ljubljana: Študentska založba, 43-52.

Sorabji, Cornelia (1989). Muslim Identity and Islamic Faith in Sarajevo. Doctoral dissertation. Cambridge: University of Cambridge.

Talam, Jasmina (2015). Pripovijedanje kroz pjesmu kao dio ženskog tradicionalnog muzičkog izraza u Bosni i Hercegovini. Žene nositeljice narodne muzičke prakse u Bosni i Hercegovini (Women as Bearers of Folk Music Practices in Bosnia and Herzegovina) (eds. Tamara Karača Beljak, Jasmina Talam). Sarajevo: Muzička akademija Univerziteta u Sarajevu, ICTM Nacionalni komitet Bosne i Hercegovine, 34-49.

Toplak, Kristina (2008). Buenas artes: Ustvarjalnost Slovencev in njihovih potomcev v Buenos Airesu. Ljubljana: Založba ZRC, ZRC SAZU.

Toska, Amra (2015). Žena kao izvorište i nositeljica kontinuiteta sevdalinke. Žene nositeljice narodne muzičke prakse u Bosni i Hercegovini (Women as Bearers of Folk Music Practices in Bosnia and Herzegovina) (eds. Tamara Karača Beljak, Jasmina Talam). Sarajevo: Muzička akademija Univerziteta u Sarajevu, ICTM Nacionalni komitet Bosne i Hercegovine, 66-87.

Turino, Thomas (2004). Introduction: Identity and the Arts in Diaspora Communities. Identity and the Arts in Diaspora Communities (eds. Thomas Turino, James Lea). Warren, Mi.: Harmonic Park Press, 3-21.

Vidmar Horvat, Ksenija (2014). Predgovor: Ženskam naproti. Ženske na poti, ženske napoti: Migrantke v slovenski nacionalni imaginaciji (Women Away, Women on the Way: Female Migrations in the Slovene National Imagination) (ed. Ksenija Vidmar Horvat). Ljubljana: Univerza v Ljubljani, Filozofska fakulteta, 7-10.

Vrečer, Natalija (2007). Integracija kot človekova pravica: Prisilni priseljenci iz Bosne in Hercegovine v Sloveniji. Ljubljana: Založba ZRC, ZRC SAZU, Andragoški center Republike Slovenije.

Yuval-Davis, Nira (2003). Nationalist projects and gender relations. Narodna umjetnost 40/1, 9-36. 


\section{POVZETEK}

\section{SPOL IN GLASBENO USTVARJANJE V BEGUNSTVU: BOSANSKO-HERCEGOVSKE GLASBENICE BEGUNKE V SLOVENIJI Alenka BARTULOVIĆ, Miha KOZOROG}

Begunska glasbena ustvarjalnost ostaja obrobna tema v raziskovanju migracij. Pričujoči članek bosansko-hercegovske begunke v Sloveniji v začetku devetdesetih let 20. stoletja obravnava kot glasbenice in organizatorke glasbenih dejavnostih. Obenem obravnava njihovo pogajanje o spolni identiteti, ki ga je omogočalo glasbeno ustvarjanje. V središču raziskave sta glasbeni skupini Dertum in Vali, nastali v Ljubljani kot del širšega begunskega delovanja, v obeh pa so pomembno vlogo odigrale prav begunke. Tako se članek pridružuje tistim raziskavam migracijskih procesov, ki upoštevajo vlogo spola, obenem pa raziskavam, ki se posvečajo vlogi umetnosti in glasbe pri soočanju z begunstvom. Članek ugotavlja, da je v obravnavanem obdobju slovenska migracijska politika beguncem omejevala dostop do dela, moške in ženske pa postavljala v neenak položaj na trgu dela, $s$ čimer so se medspolna razmerja spreminjala. Kot osnovo za razumevanje transformacije medspolnih razmerij članek jemlje spolne vloge v Bosni in Hercegovini v času Jugoslavije in po njej. V procesu spreminjanja medspolnih razmerij je za segment beguncev igralo pomembno vlogo glasbeno ustvarjanje, $\mathrm{s}$ katerim so glasbenice spreminjale lastno pozicijo $\mathrm{v}$ begunski skupnosti, obenem pa so aktivno vplivale na percepcijo in sprejemanje beguncev in begunk v slovenski družbi. Članek prikaže okoliščine begunstva in osebne motive za glasbeno delovanje izbranih glasbeno aktivnih begunk. Posebno pozornost namenja glasbeni obliki sevdalinki kot domnevno »avtentični« bosansko-hercegovski glasbi, ki sta jo v svojem repertoarju imeli obe obravnavani glasbeni skupini. Ker so medspolna razmerja vpisana tudi v obravnavano glasbeno tradicijo, je njeno preobražanje v razmerah begunstva puščalo določene sledi v razmerjih znotraj begunske skupnosti. 